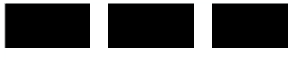 \\ $\square \square$ \\ THE WiLliam DAVIDSON INSTITUTE \\ AT THE UNIVERSITY OF MICHIGAN BUSINESS SCHOOL
}

\section{Languages in the European Union: The Quest for Equality and its Cost}

By: Jan Fidrmuc and Victor Ginsburgh

William Davidson Institute Working Paper Number 715

July 2004 


\title{
Languages in the European Union: The Quest for Equality and its Cost
}

\author{
Jan Fidrmuc \\ ECARES, Université Libre de Bruxelles; \\ ZEI, University of Bonn and \\ CEPR and WDI \\ and \\ Victor Ginsburgh \\ ECARES, Université Libre de Bruxelles and \\ CORE, Université Catholique de Louvain
}

July 2004

\begin{abstract}
The European Union has recently expanded from 15 to 25 countries. In line with this enlargement, the list of official EU languages has grown from 11 to 20. Currently, the EU extends equal treatment to all member countries' official languages by providing translations for documents and interpreting services for meetings and sessions of the European Parliament. This, however, is costly, especially when recognizing that many Europeans speak one of the procedural languages of the EU, English, French or German, either as their native language or as a foreign language. We compute disenfranchisement rates that would result from using only the three procedural languages for all EU business, and marginal costs per disenfranchised person associated with providing translations and interpreting into the remaining 17 languages. The marginal costs are shown to vary substantially across the different languages, raising important questions about the economic efficiency of equal treatment for all languages. We argue that an efficient solution would be to decentralize the provision of translations.
\end{abstract}

JEL Codes: D70, O52, Z13.

Keywords: Languages, Disenfranchisement, European Union, Cost and benefit analysis.

\footnotetext{
* Address: ECARES, Université Libre de Bruxelles, 50 Avenue F.D. Roosevelt, CP 114, 1050 Brussels, Belgium. Email: Jan Fidrmuc: JFidrmuc@ulb.ac.be. Phone: +32-2-650-4462, Fax: +32-2-650-3369. Victor Ginsburgh: vginsburg@ulb.ac.be. Phone: +32-2-650-3846, Fax: +32-2-650-4012.
} 


\section{Introduction}

The European Commission claims that, before the latest enlargement, 57.4 percent of its documents were initially prepared in English, 29.1 percent in French, and 4.6 percent in German. The remaining eight languages thus accounted for less than 9 percent of inputs into EU business. The situation is strikingly different on the output side, however: most documents subsequently get translated into all official languages of the EU and the structure of output is thus highly egalitarian. With the enlargement from 15 to 25 countries and the resulting growth in the number of official languages from 11 to 20, the disparity between the input and output sides will become even more glaring. ${ }^{1}$

Equal linguistic treatment, while laudable, comes at a considerable cost to the EU. The EU15 was spending some EUR 686 million annually on translating and interpreting services. In the wake of enlargement, this cost is envisaged to rise to EUR 1.236 billion. By 2004, the EU was employing 2,400 translators (not counting external and free-lance collaborators) and was translating one and a half million pages annually. ${ }^{2}$ The number of translators is to rise by a further 376 by September 2004 to accommodate the languages of the new member countries. There are also non-monetary costs of equal treatment: the EU currently has a backlog of 60,000 pages awaiting translation. In some cases, important directives could not take effect because they were not translated in time. ${ }^{3}$ This has lead to some drastic (and borderline absurd) measures such as requiring that reports and communications do not exceed some maximum length (e.g. 15 pages for communications and explanatory texts as of May 2004) ${ }^{4}$ or instructing the Members of the European Parliament to use simple sentences and to avoid jokes.

This generous and comprehensive approach is largely unique to the EU. Most linguistically diverse countries only award the official status to one or two core languages:

\footnotetext{
1 The EU distinguishes between procedural and official languages. The former, English, French and German, are used for day-to-day running of the EU bureaucracy. Official languages are used at the sessions of the European Parliament and EU summit meetings. Furthermore, official documents, resolutions and directives prepared and adopted by the EU are translated to all official languages, and EU citizens and firms are entitled to communicate with the EU in their national language. This privilege, however, does not extend to minority languages such as Welsh, Irish, Catalan, Basque or Russian, even when they have an official or semi-official status in their own country.

2 European Commission (2004). Vanden Abeele (2004), who until 2003 was the Commission director general in charge of re-organizing translation and interpreting services, reports that the total number of translators, interpreters and their support staff employed by the various EU institutions is approximately 6000.

3 In May 2004, the implementation of new directives on financial regulation and transparency of securities information had to be delayed by six months because they were not translated in time (see WSJE, 2004). As the EU has expanded in the meantime, the directives now have to be translated also into nine additional languages.
} 
English in the UK, the US and most of former British colonies, Spanish in Spain and most of Latin America, Russian in Russia, Mandarin in China or English and Hindi in India, despite the presence of large and often regionally concentrated linguistic minorities.

Without a reform, the list of official EU languages is likely to grow even further. In a few years, Bulgarian, Romanian and possibly also Croatian will be added. Turkish can be next, either because of Turkey's accession to the EU, or because of re-unification of Cyprus. Furthermore, Irish Gaelic and Luxembourgish, which have the official-language status in their respective countries, could also be become official EU languages. A number of minority languages, such as Catalan, Basque, Welsh or Russian, may follow suit.

Given the limited resources of the EU, there must be a limit beyond which adding further languages will become both unfeasible - both with respect to financing the cost of translations and providing premises and infrastructure for thousands of translators. Which languages should optimally be given the official status depends on the relevant criteria. On the one hand, it is important to ensure that EU citizens have reasonably easy access to information about EU decisions and actions and that they can communicate with the EU in a language that they understand. On the other hand, the resources spent on translating documents and speeches could be allocated to alternative, perhaps more productive and more welfare-enhancing uses. Our analysis highlights, and attempts to quantify, some of the trade-offs involved in deciding which languages the EU should optimally use.

In the following section, we discuss alternatives to equal treatment, namely, adopting a single language or a few languages as official languages to be used for all EU business and communication with EU citizens. We compare the disenfranchisement rates ${ }^{5}$ that would result from alternative scenarios, both for the EU15 and, in light of the recent enlargement, also EU25. Then, in section 3, we compute the marginal costs per disenfranchised person of keeping each of the remaining EU languages on the list of official languages. The last section summarizes our findings and argues that the EU should decentralize the decision on translations.

\footnotetext{
${ }^{4}$ See European Commission (2004).

${ }^{5}$ A person is linguistically disenfranchised when he/she does not speak any of the official languages either as a native a second (or third) language.
} 


\section{Language Choices and Disenfranchisement}

The 20 official languages are not equally used by the EU population at large: not only because some nations are larger than others but also because some languages are more popular among Europeans when it comes to learning and speaking foreign languages. In fact, the importance of the three procedural languages approximately mirrors their relative shares among the EU15 population (if not in magnitude then at least in ordering): 55 percent speak English, 34 percent French, and 17 percent German. ${ }^{6}$ It is more instructive, however, to consider combinations of languages. ${ }^{7}$ Thus, 70 percent of the EU15 population is proficient either in English or in French. This means that if these two languages were used as official languages of the EU15, 70 percent of the population would be able to follow EU actions and decisions, without any further translation of EU documents or speeches in the Parliament. The English-German combination fares very similarly: 68 percent of the EU15 population knows either English or German. Thus, when considering scenarios for linguistic reform, there is almost no difference between the English-French and English-German alternatives. Finally, 81 percent of EU15 population knows at least one of these three languages. This is shown in the first part of Table 1, though the numbers are expressed, more dramatically as the percentage of the population of each country (and of the EU15) that would be lost (disenfranchised) if only one language or a group of languages (English-French, English-German, and English-French-German) were to be used as official languages.

Note that these are EU15 averages (weighted by the populations in each country) do not do full justice to what happens in individual countries. The results shown in Table 1 make it clear that there are very large differences across countries, and that irrespective of the choice, some countries such as Greece, Italy, Portugal, and Spain would suffer large (near or exceeding

\footnotetext{
${ }^{6}$ Most of the numbers concerned with the EU15 are taken from Ginsburgh and Weber (2003) and are based on a Eurobarometer survey on languages that was run in 2000. The questions asked in the survey were concerned with all the languages used by citizens in the 15 countries of the EU. Ginsburgh and Weber (2003) consider that a person "knows" a language if she declares it as her mother tongue, or as a second or third language. Clearly, there are individuals who tend to declare that they know a language, though their knowledge is basic; others may be shy and refrain from doing so. Therefore all the numbers must be taken with a pinch of salt, though they are much better than nothing, which is the basis for most of what is written about languages. The survey alluded to is the most complete and recent dataset that exists, and unless one has 15,000 people taking proficiency tests in several languages, it will be difficult to do any better.

7 The calculation is not as straightforward, since one has to eliminate double counting. If one wants to analyze who speaks English or French, one can add those who speak English to those who speak French, but one has to subtract those who speak both. See Ginsburgh and Weber (2003)
} 
50 percent) disenfranchisement rates, since none of the three languages discussed is widely spoken in these countries.

Naturally, the relative importance of these three languages is different in today's EU 25. The distribution of English, French and German among the newcomers is shown in the second part of Table $1 .^{8}$ The figures for the new members and candidate countries are much lower than those for the EU15: 15 percent are proficient in English, 2 percent in French and 4 percent in German. This is not surprising, given that none of these countries has English, French or German as their native language (with the exception of Malta, where English is an official language in parallel to Maltese). Again, there are differences across nations: Cyprus, Malta and Slovenia are reasonably proficient in English, ${ }^{9}$ French is almost unknown everywhere, and the only country where German is widely diffused is Slovenia - though even there it lags behind English (the dominant position of English is shared by all newcomers except the Czech Republic and Slovakia, where German is more popular).

The interesting - though not unexpected - result, however, is that German does better than French. Table 2 shows how this translates into the enlarged EU. First, the enlargement dramatically increases disenfranchisement rates for all alternative scenarios. No language, not even English, is spoken by more than 50 percent of the population of EU25. Second, the position of German is strengthened so that, after enlargement, the English-French and English-German alternatives are on equal footing. Both choices disenfranchise no more than 37 percent of the EU population and hence there is no reason to prefer one combination over the other. With all three languages, over one quarter of the EU25 would still remain disenfranchised.

Negotiations between the EU, and Bulgaria and Rumania are ongoing, and the odds that Turkey will enter the EU in the foreseeable future are not negligible. Therefore, we also look at what would happen if these three countries were to be included. ${ }^{10}$ The last part of Table 1 displays the detailed results, ${ }^{11}$ which show that Rumania is slightly better in language proficiency than Bulgaria and Turkey. Rumania is also the only country where French is more

\footnotetext{
8 This is based on a Candidate Countries' Eurobarometer survey (see DG Press and Communication, 2003). Of course, one can wonder whether the two sets of answers on the two surveys (EU 15, and newcomers) are identical. The answer is, as expected, negative, as the wording of the relevant questions, or the set of languages to choose from, while similar, were not identical.

${ }^{9}$ It is even surprising that $17 \%$ of Maltese do not know English, given that English has the status of an official language in Malta (alongside Maltese)!

10 Croatia recently also became a candidate for EU membership. Unfortunately, it is not covered by our data.

11 These numbers are based on the same Candidate Countries Eurobarometer survey.
} 
widely used than German, but this is far from being sufficient to give a push to French to make the English-French alternative look better than the English-German one. As Table 2 shows, both two-language scenarios give comparable results. Disenfranchisement rates rise to 45 percent in either case, while the three-language alternative would result in 35 percent of the population being disenfranchised.

\section{Marginal Cost per Language}

The annual cost of translating and interpreting in the EU15, with 11 official languages, was EUR 686 million. Assuming that all languages are treated equally (i.e. each document or oral statement is translated into all languages) and that all 11 languages are equally costly to translate to and from, this amounts to EUR 68.6 million per language. ${ }^{12}$ The expansion to EU25 is expected to add an additional EUR 550 million to this bill, or EUR 61.1 million per new language. ${ }^{13}$ The total annual cost will thus be EUR 1.236 billion and the average cost per language falls slightly to EUR 65 million. This saving is actually quite a remarkable achievement, as by adding nine new languages, the number of language combinations requiring translations and interpreting will rise considerably (the EU insists, however, that this savings will not affect only the new member countries, rather, the cost-reducing measures are to be applied equally to all countries). The saving is, in part, to be achieved by greater reliance on relay translations and interpreting, so that, for example, a translation from Greek to Estonian will not be done directly but the document will first be translated into a relay language such as English and only then to Estonian. While reducing the costs considerably, this method may cause delays and increase the potential for errors. Furthermore, the European Commission has indicated that it would extend the definition of documents and communications, which are to be carried only in the three procedural languages. ${ }^{14}$

Although the total costs of giving all languages official status seems very high, it only amounts to EUR 1.8 per person in EU15 and EUR 2.75 in EU25 (however, the average cost per person in the ten new countries is much higher, EUR 7.3, reflecting the fact that, except for

\footnotetext{
12 This is the total cost, divided by 10 , as a document prepared in any of the 11 official languages has to be translated into the remaining ten languages.

13 The expansion will add nine new official languages: Czech, Estonian, Hungarian, Latvian, Lithuanian, Maltese, Polish, Slovak and Slovene (Cyprus, being a Greek speaking country, will not require a new official EU language).

14 In particular, this should be the case with respect to internal documents and communications (both written and oral) that concern only the Commission. See European Commission (2004).
} 
Poland, these are all small or medium sized countries). These costs are modest and it seems that spending 2 or 3 euros per year to ensure that no EU citizen is disenfranchised is indeed good value for money. However, average costs are not necessarily the right figure to consider. It is instructive to look instead at the marginal cost per person who would be disenfranchised had EU documents not been provided in his/her native language. This allows for considerable differences across languages, because of differences in the populations that speak each language and because countries differ in terms of proficiency in foreign languages.

Table 3 summarizes the results. The first column lists the overall population speaking each language, taking account of the fact that English, German, French, Dutch and Greek are spoken in more than one country in the EU25. ${ }^{15}$ The next four columns list the numbers of people who would become disenfranchised in the four alternative scenarios of linguistic reform: the official languages being only English (scenario denoted E), English and French (EF), English and German (EG), or English, French and German (EFG). Finally, the last four columns report the marginal costs per disenfranchised person (in Euros) that would arise from adding their language to the list of official languages, again for the same three scenarios. Finally, the last row reports the total number of persons who would end up being disenfranchised in each scenario and corresponding average costs of providing translations per disenfranchised person.

In making the calculations, we assume, in line with EU pronouncements, that all languages will be treated equally and thus the cost per language is EUR 65.1 million for old and new EU members alike (we cannot include Bulgarian, Romanian and Turkish in our analysis as no cost estimates are available for these three languages). Note that the cost is computed per language rather than per country because English, French, German, Dutch and Greek are each spoken in two countries in the EU25.

Several further assumptions underlie the analysis. Our calculation disregards the inconvenience aspect of receiving information in languages other than one's mother's tongue: the costs of providing translations and interpreting services into a language are divided by the number of those for whom EU documents would be completely inaccessible if they were only available in two or three official languages. The exercise also ignores other aspects such as the feeling of national pride, patriotism and international recognition that are strengthened by having

\footnotetext{
15 These countries are the U.K. and Ireland in the case of English, France and Belgium (40 percent of population) for French, Germany and Austria for German, the Netherlands and Belgium (60 percent) for Dutch, and Greece and Cyprus for Greek.
} 
one's language elevated to the status of an official language of the EU. Finally, linguistic minorities whose languages currently do not have an official status at the EU level, such as Irish, Welsh, Catalan, Basque, and Russian, are not considered in the calculation either.

The calculation is illuminating. First, the costs of providing translation into French and German are very low: 1.7 and 1.6 euro, respectively, in the English-only scenario. The costs are almost the same also when considering two-language scenarios: providing translations into German costs again 1.6 euro in the EF case, while the cost of French translations in the EG scenario is 1.8 euro.

Second, there are large differences across countries. The cost of providing translations to a language reflects the combined effect of the number of people who speak the language and the number of speakers of that language who are proficient in foreign languages: the more people speak a language, ceteris paribus, the lower the cost, but the more speakers of that language speak English, German or French, the lower the need of providing translations and hence the higher the cost per disenfranchised person. Because of these two effects, languages spoken by large populations are relatively inexpensive: Italian, Spanish and Polish each cost 3 euros or less per disenfranchised person in the three-language scenario; Dutch, Portuguese, Greek, Czech, Hungarian, Lithuanian and Slovak are in the range of approximately 10 to 25 euros per person. In contrast, languages spoken by relatively few people who at the same time tend to be proficient in other languages come out as relatively expensive: Finnish (35 euros), Swedish, Latvian (40 euros each), Estonian (75 euros), Danish (77 euros), and Slovene (120 euros). While these costs are by no means excessively high, one might want to consider the tradeoffs entailed in spending 35 to 120 euros per person on translations and interpreting instead of devoting them to other worthy causes. Finally, the case of Maltese is truly spectacular: with only 66 thousand Maltese left disenfranchised if English, French and German were adopted as official languages of the EU, the costs of providing translating and interpreting services to and from Maltese is nearly one thousand euros per person per year! One may wonder whether the persons concerned, or the Maltese government, would optimally choose to spend this amount on translations if the 65 million euros were completely at their discretion.

Third, introducing French and/or German alongside English makes considerable difference but only for some languages. The basic regularity is that the more languages are already being used by the EU, the more expensive it is to add other languages. This is because when moving, for example, from two languages to three, the number of disenfranchised persons 
falls in most countries and thus the cost per person rises. Hence, the average cost per disenfranchised person is 5.5 euro in the English-only scenario, 7 euros in either EF or EG scenario and 10 euros for the EFG alternative. The difference in marginal costs across scenarios is most pronounced in the case of the Dutch language: the cost per disenfranchised person doubles when French is added to English and almost triples when moving from English only to the EFG scenario. Slovene, Danish, Czech and Slovak also show large variations across the four scenarios. For most of the other languages, the difference in costs is not very large. For Greek and Maltese, finally, English is essentially the only language that matters.

The figures discussed above clearly are merely simple back-of-the-envelope calculations. Nonetheless, they give a good indication of the order of magnitude of the marginal costs of providing translations for the various European languages. The main limitation of our analysis is that it is static in that we assume adding one language at a time to the initial list of one or two languages. Clearly, sequencing is important. On the one hand, a translation may be easier (and cheaper) if it involves two closely related languages. Thus, translating a document from Spanish to Portuguese, from Swedish to Danish or from Czech to Slovak will entail lower costs than translating the same document from English. ${ }^{16}$ Such relay translation, however, while reducing the cost, also increases the probability of errors and mistakes. On the other hand, once Spanish, Swedish and Czech are official languages, the number of disenfranchised Portuguese, Danes and Slovaks is likely to drop considerably, thus resulting in different, and higher, marginal cost of providing translations into Portuguese, Danish and Slovak. Thus, depending on sequencing, the marginal costs can be higher or lower than those we present in Table 3.

\section{Conclusions}

As the EU expands to include ever more countries, the trade off between equal treatment and economic efficiency becomes increasingly apparent. It is obviously important to ensure that citizens of Europe have access to relevant information about EU actions and decisions in a language that they can understand. Yet, translating tens of thousands of documents per year into 20 different languages and providing interpreting services for EU meetings and sessions of the

\footnotetext{
16 To take this into account, one may weight translation costs by the level of difficulty, which can be measured by the distances between languages, computed for instance by Dyen, Kruskal and Black (1992).
} 
European Parliament is very costly. ${ }^{17}$ As the number of official EU languages increases, so do the various inefficiencies inherent to a multi-lingual organization such as the EU. Example abound: National representatives at meetings and Members of the European Parliament can speak in their own language because that allows them to make their arguments in a more sophisticated and nuanced way. However, only a small fraction of their audience enjoys the full benefit of this privilege; the rest hear a translation, possibly one that involved a relay language and that may be imprecise or outright erroneous. The need for translations delays EU decisions and results in an ever growing backlog of documents awaiting translation. And the latest enlargement highlighted yet another problem: the sheer difficulty of finding sufficient number of translators and interpreters for languages spoken in some of the smallest EU member countries.

Our analysis highlights the differences across the various nations and linguistic groups in their ability to speak other languages. The need for translations would disappear in a hypothetical world where everyone speaks a common language in addition to her mother's tongue. The EU25 is rather far from that at present: even English, the most common second language in Europe, is spoken by less than half of the population. Adding either French or German, however, brings down the disenfranchisement rate to 37 percent, and adopting all three languages translates into further gains, leaving approximately one quarter of the EU25 population disenfranchised.

If only English, French and German were to be used as official languages of the EU, the differences in disenfranchisement rates across countries would remain considerable. Therefore, it is instructive to consider the marginal costs per disenfranchised person of extending the official status to the remaining 17 languages. Our analysis shows that, for a number of languages, the benefits of eliminating disenfranchisement clearly outweigh the marginal costs. Nonetheless, several smaller languages could be considered border cases, at least when judged on the merits of economic efficiency - though political considerations are likely to play an important role as well. Having access to documents in one’s own language increases one’s welfare, but the same resources might be spent more efficiently on other welfare enhancing measures. Though, as pointed out by Neil Kinnock, Vice-President of the European Commission, the average cost of providing translations is low (1.8 euro per EU citizen before the latest enlargement), our analysis

\footnotetext{
17 Ironically, sometimes this effort produces results that go against the objective of providing the citizens of Europe with information in their own language. The debates of the European Parliament, for instance, are published on the internet with the individual contribution recorded only in the speaker's language. One thus has to be able to read numerous languages (and alphabets!) to understand who said what.
} 
shows that for some languages the cost is exorbitant, even approaching one thousand euros per person.

Obviously, changing the current EU language policy by designating some languages as more important than others, while perhaps pragmatic, would be highly controversial and probably politically unacceptable. An economically efficient and uncontroversial solution presents itself in decentralization of the decision on providing translation services. Thus, rather than taking away resources from some, the individual countries should be given discretion over the resources earmarked for translating services. Many countries would certainly wish to continue the current regime of extensive translations and interpreting. However, some countries might deem the funds better spent on education, health care or other worthy causes. ${ }^{18}$

It is reasonable to expect that the case for linguistic reform will grow stronger in the future: both Eurobarometer surveys used in this paper suggest that the younger population is more proficient in foreign languages, which implies a further increase in the marginal costs of providing translations per disenfranchised person. ${ }^{19}$ Moreover, the costs of any linguistic reform will be only transitory, as the reform will induce people to invest into learning the languages used by the EU.

\footnotetext{
18 Note that the decision on languages spoken in more than one country would have to be made jointly by the countries concerned, i.e. Netherlands and Belgium for Dutch and Greece and Cyprus for Greek (assuming English, French and German were to remain official EU languages). Those countries would also need to agree on a formula for splitting the funds in case they choose not to spend them on translation services.

${ }^{19}$ However, a recent report by the French Ministry of Education (2004), comparing the levels of foreign languages among French high school students is rather pessimistic in this respect.
} 


\section{References}

DG Press and Communication (2003), Applicant Countries Eurobarometer 2001: Public Opinion in the Countries Applying for European Union Membership, European Commission, March 2002.

Dyen, I, J. B. Kruskal, and P. Black (1992), An Indo-European classification: A lexicostatistical experiment, Transactions of the American Philosophical Society 82.

European Commission (2004), Commission adopts measures to match supply and demand for translation, IP/04/679, Brussels, May 2004.

French Ministry of Education (2004), Evaluation des compétences en anglais des élèves de 15 à 16 ans dans sept pays européens, http://www.education.gouv.fr/stateval (March 2004).

Ginsburgh, Victor and Shlomo Weber (2003), Language disenfranchisement in the European Union, manuscript.

INRA (2001), Eurobaromètre 54 Special, Les Européens et les langues.

Vanden Abeele, Michel (2004), Les langues dans l'Union Européenne: au delà des combats d'arrière garde, Conference at Université Libre de Bruxelles, February 9, 2004.

WSJE (2004), “A Welcome Break,” Editorial. Wall Street Journal Europe, May 17, 2004, p. A8 
Table 1 Country Disenfranchisement Rates

(in \% of total population)

\begin{tabular}{|c|c|c|c|c|c|c|c|}
\hline & $\begin{array}{c}\text { Population } \\
\text { [millions] }\end{array}$ & $\mathbf{E}$ & $\mathbf{F}$ & G & EF & EG & EFG \\
\hline \multicolumn{8}{|c|}{ EU15 } \\
\hline Austria & 8.1 & 54 & 89 & 1 & 52 & 0 & 0 \\
\hline Belgium & 10.2 & 60 & 25 & 90 & 18 & 53 & 17 \\
\hline Denmark & 5.3 & 25 & 95 & 63 & 24 & 16 & 16 \\
\hline Finland & 5.1 & 39 & 99 & 93 & 39 & 37 & 36 \\
\hline France & 60.4 & 58 & 0 & 92 & 0 & 57 & 0 \\
\hline Germany & 82 & 46 & 84 & 3 & 44 & 0 & 0 \\
\hline Greece & 10.5 & 53 & 88 & 88 & 53 & 52 & 51 \\
\hline Italy & 57.6 & 61 & 71 & 96 & 48 & 59 & 47 \\
\hline Ireland & 3.7 & 5 & 77 & 94 & 4 & 4 & 3 \\
\hline Luxembourg & 0.4 & 81 & 9 & 26 & 4 & 15 & 1 \\
\hline Netherlands & 15.8 & 30 & 81 & 41 & 20 & 15 & 14 \\
\hline Portugal & 10.8 & 65 & 72 & 98 & 59 & 64 & 58 \\
\hline Spain & 39.4 & 64 & 81 & 98 & 57 & 63 & 56 \\
\hline Sweden & 8.9 & 21 & 93 & 69 & 20 & 19 & 18 \\
\hline United Kingdom & 58.6 & 1 & 78 & 91 & 1 & 1 & 1 \\
\hline Together & 376.9 & 45 & 66 & 83 & 30 & 32 & 19 \\
\hline \multicolumn{8}{|c|}{ Countries that joined on May 1, 2004} \\
\hline Cyprus & 0.8 & 39 & 93 & 98 & 38 & 39 & 38 \\
\hline Czech Republic & 10.3 & 76 & 97 & 70 & 75 & 54 & 53 \\
\hline Estonia & 1.4 & 69 & 99 & 86 & 69 & 62 & 62 \\
\hline Hungary & 10.1 & 85 & 98 & 86 & 84 & 75 & 75 \\
\hline Latvia & 2.4 & 77 & 99 & 86 & 76 & 68 & 67 \\
\hline Lithuania & 3.6 & 80 & 98 & 88 & 79 & 72 & 70 \\
\hline Malta & 0.4 & 17 & 91 & 99 & 17 & 17 & 17 \\
\hline Poland & 38.6 & 80 & 97 & 83 & 78 & 67 & 66 \\
\hline Slovakia & 5.4 & 87 & 98 & 79 & 86 & 72 & 71 \\
\hline Slovenia & 2 & 47 & 96 & 57 & 46 & 28 & 27 \\
\hline Together & 75 & 85 & 98 & 96 & 77 & 65 & 64 \\
\hline \multicolumn{8}{|c|}{ Candidate Countries } \\
\hline Bulgaria & 7.9 & 87 & 95 & 94 & 83 & 83 & 80 \\
\hline Rumania & 21.8 & 80 & 83 & 95 & 71 & 77 & 68 \\
\hline Turkey & 65.6 & 85 & 98 & 96 & 84 & 82 & 81 \\
\hline Together & 95.3 & 84 & 94 & 96 & 81 & 81 & 74 \\
\hline
\end{tabular}


Table 2 Average Disenfranchisement rates

(in \% of total population)

\begin{tabular}{lrllllll}
\hline & $\begin{array}{c}\text { Population } \\
\text { (millions) }\end{array}$ & E & F & G & EF & EG & EFG \\
\hline EU 15 & 376.9 & 45 & 66 & 83 & 30 & 32 & 19 \\
EU 25 & 451.9 & 52 & 71 & 85 & 37 & 37 & 26 \\
EU 28 & 547.2 & 57 & 75 & 87 & 45 & 45 & 35 \\
\hline
\end{tabular}

Notes. E: English, F: French; G: German; EF: English and French; EG: English and German; EFG: English, French and German 
Table 3 Marginal costs per person disenfranchised

(population in millions, costs in EUR)

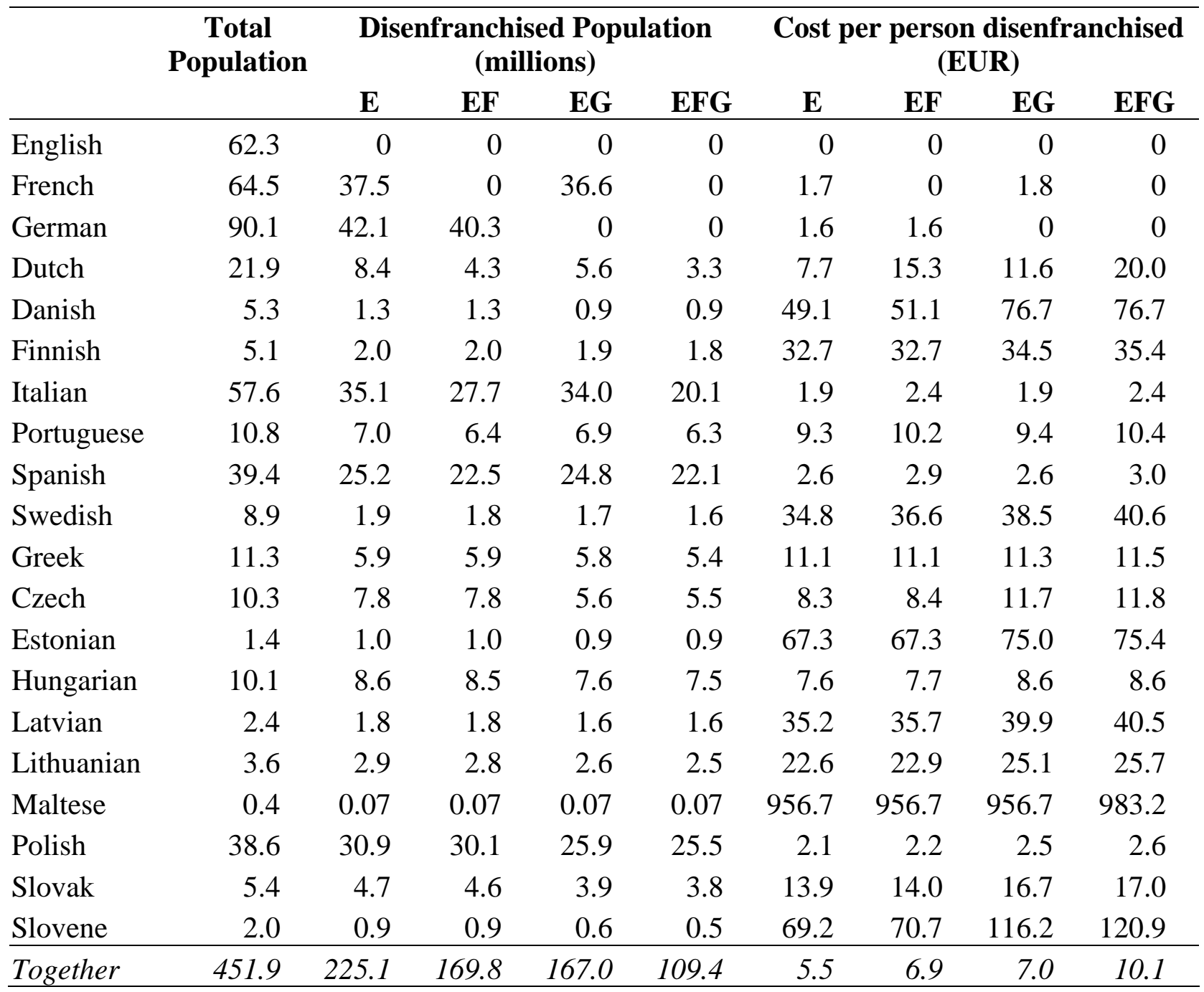




\section{DAVIDSON INSTITUTE WORKING PAPER SERIES - Most Recent Papers}

The entire Working Paper Series may be downloaded free of charge at: www.wdi.bus.umich.edu

CURRENT AS OF 7/26/04

\begin{tabular}{|c|c|c|}
\hline Publication & Authors & Date \\
\hline $\begin{array}{l}\text { No. 715: Languages in the European Union: The Quest for Equality and } \\
\text { its Cost }\end{array}$ & $\begin{array}{l}\text { Jan Fidrmuc and Victor } \\
\text { Ginsburgh }\end{array}$ & July 2004 \\
\hline $\begin{array}{l}\text { No. 714: Voice of the Diaspora: An Analysis of Migrant Voting } \\
\text { Behavior }\end{array}$ & Jan Fidrmuc and Orla Doyle & July 2004 \\
\hline $\begin{array}{l}\text { No. 713: International Coercion, Emulation and Policy Diffusion: } \\
\text { Market-Oriented Infrastructure Reforms, 1977-1999 }\end{array}$ & $\begin{array}{l}\text { Witold J. Henisz and Bennet A. } \\
\text { Zelner and Mauro F. Guillen }\end{array}$ & July 2004 \\
\hline $\begin{array}{l}\text { No. 712: Votes and Vetoes: The Political Determinants of Commercial } \\
\text { Openness }\end{array}$ & $\begin{array}{l}\text { Witold J. Henisz and Edward D. } \\
\text { Mansfield }\end{array}$ & July 2004 \\
\hline $\begin{array}{l}\text { No. 711: Interest Groups, Veto Points and Electricity Infrastructure } \\
\text { Deployment }\end{array}$ & $\begin{array}{l}\text { Witold J. Henisz and Bennet A. } \\
\text { Zelner }\end{array}$ & July 2004 \\
\hline $\begin{array}{l}\text { No. 710: Firms' Price Markups and Returns to Scale in Imperfect } \\
\text { Markets: Bulgaria and Hungary }\end{array}$ & $\begin{array}{l}\text { Rumen Dobrinsky, Gábor Körösi, } \\
\text { Nikolay Markov, and László } \\
\text { Halpern }\end{array}$ & July 2004 \\
\hline $\begin{array}{l}\text { No. 709: The Stability and Growth Pact from the Perspective } \\
\text { of the New Member States }\end{array}$ & Gábor Orbán and György Szapáry & July 2004 \\
\hline $\begin{array}{l}\text { No. 708: Contract Violations, Neighborhood Effects, and Wage Arrears } \\
\text { in Russia }\end{array}$ & $\begin{array}{l}\text { John S. Earle and Klara } \\
\text { Sabirianova Peter }\end{array}$ & July 2004 \\
\hline $\begin{array}{l}\text { No. 707: Determinants of Employment Growth at MNEs: Evidence } \\
\text { from Egypt, India, South Africa and Vietnam }\end{array}$ & $\begin{array}{l}\text { Sumon Kumar Bhaumik, Saul } \\
\text { Estrin and Klaus Meyer }\end{array}$ & July 2004 \\
\hline $\begin{array}{l}\text { No. 706: Economic Reform in Tanzania and Vietnam: A Comparative } \\
\text { Commentary }\end{array}$ & $\begin{array}{l}\text { Brian Van Arkadie and Do Duc } \\
\text { Dinh }\end{array}$ & June 2004 \\
\hline $\begin{array}{l}\text { No. 705: Beliefs about Exchange-Rate Stability: Survey Evidence } \\
\text { from the Currency Board in Bulgaria }\end{array}$ & $\begin{array}{l}\text { Neven T. Valev and John A. } \\
\text { Carlson }\end{array}$ & June 2004 \\
\hline No. 704: Returns to Schooling in China Under Planning and Reform & $\begin{array}{l}\text { Belton M. Fleisher and Xiaojun } \\
\text { Wang }\end{array}$ & June 2004 \\
\hline $\begin{array}{l}\text { No. 703: Return to Skills and the Speed of Reforms: Evidence from } \\
\text { Central and Eastern Europe, China and Russia }\end{array}$ & $\begin{array}{l}\text { Belton M. Fleisher, Klara } \\
\text { Sabirianova Peter, and Xiaojun } \\
\text { Wang }\end{array}$ & June 2004 \\
\hline $\begin{array}{l}\text { No. 702: What Makes Small Firms Grow? Finance, Human Capital, } \\
\text { Technical Assistance, and the Business Environment in Romania }\end{array}$ & $\begin{array}{l}\text { J. David Brown, John S. Earle } \\
\text { and Dana Lup }\end{array}$ & May 2004 \\
\hline $\begin{array}{l}\text { No. 701: The Effects of Multiple Minimum Wages Throughout the } \\
\text { Labor Market }\end{array}$ & $\begin{array}{l}\text { T. H. Gindling and Katherine } \\
\text { Terrell } \\
\end{array}$ & May 2004 \\
\hline No. 700: Minimum Wages, Inequality and Globalization & $\begin{array}{l}\text { T. H. Gindling and Katherine } \\
\text { Terrell }\end{array}$ & May 2004 \\
\hline No. 699: Self-Selection and Earnings During Volatile Transition & Ralitza Dimova and Ira Gang & May 2004 \\
\hline No. 698: Ecology and Violence: The Environmental Dimensions of War & $\begin{array}{l}\text { Timothy L. Fort and Cindy A. } \\
\text { Schipani }\end{array}$ & May 2004 \\
\hline $\begin{array}{l}\text { No. 697: Russian Cities in Transition: The Impact of Market Forces in } \\
\text { the 1990s }\end{array}$ & Ira N. Gang and Robert C. Stuart & May 2004 \\
\hline $\begin{array}{l}\text { No. 696: Firm Ownership and Internal Labor Practices in a Transition } \\
\text { Economy: An Exploration of Worker Skill Acquisition in Vietnam }\end{array}$ & Jed Friedman & May 2004 \\
\hline No. 695: The Unanticipated Effects of Insider Trading Regulation & $\begin{array}{l}\text { Art A. Durnev and Amrita S. } \\
\text { Nain }\end{array}$ & May 2004 \\
\hline $\begin{array}{l}\text { No. 694: Volatile Interest Rates, Volatile Crime Rates: A New } \\
\text { Argument for Interest Rate Smoothing }\end{array}$ & Garett Jones and Ali M. Kutan & May 2004 \\
\hline $\begin{array}{l}\text { No. } 693 \text { Money Market Liquidity under Currency Board - Empirical } \\
\text { Investigations for Bulgaria }\end{array}$ & $\begin{array}{l}\text { Petar Chobanov and Nikolay } \\
\text { Nenovsky }\end{array}$ & May 2004 \\
\hline $\begin{array}{l}\text { No. 692: Credibility and Adjustment: Gold Standards Versus Currency } \\
\text { Boards }\end{array}$ & $\begin{array}{l}\text { Jean Baptiste Desquilbet and } \\
\text { Nikolay Nenovsky }\end{array}$ & May 2004 \\
\hline $\begin{array}{l}\text { No. 691: Impact of Cross-listing on Local Stock Returns: Case of } \\
\text { Russian ADRs }\end{array}$ & Elena Smirnova & May 2004 \\
\hline $\begin{array}{l}\text { No. 690: Executive Compensation, Firm Performance, and State } \\
\text { Ownership in China:Evidence from New Panel Data }\end{array}$ & Takao Kato and Cheryl Long & May 2004 \\
\hline
\end{tabular}

